\title{
Resuscitating myth: Hollywood, Big History and transdisciplinary theology
}

\begin{tabular}{|c|c|}
\hline $\begin{array}{l}\text { Authors: } \\
\text { Gys M. Loubs } \\
\text { Calvyn C. du T }\end{array}$ & $\mathrm{r}^{1}$ \\
\hline $\begin{array}{l}\text { Affiliations: } \\
{ }^{1} \text { Department } \\
\text { and Christian } \\
\text { Faculty of The } \\
\text { Religion, Univ } \\
\text { Pretoria, Sout }\end{array}$ & $\begin{array}{l}\text { of Dogmatics } \\
\text { Ethics, } \\
\text { ology and } \\
\text { ersity of } \\
\text { h Africa }\end{array}$ \\
\hline $\begin{array}{l}\text { Research Proj } \\
\text { Project Leade } \\
\text { D.P. Veldsman } \\
\text { Project Numb }\end{array}$ & $\begin{array}{l}\text { ect Registration: } \\
\text { r: } \\
\text { (1) } \\
\text { er: } 1224719\end{array}$ \\
\hline $\begin{array}{l}\text { Project Descri } \\
\text { The authors a } \\
\text { in the researc } \\
\text { 'Religious Exp } \\
\text { an evolutiona } \\
\text { directed by Pr } \\
\text { Department D } \\
\text { Christian Ethic } \\
\text { Theology, Uni } \\
\text { Pretoria. }\end{array}$ & $\begin{array}{l}\text { ption: } \\
\text { e participating } \\
\text { p project, } \\
\text { erience from } \\
\text { y perspective', } \\
\text { of. Dr Veldsman, } \\
\text { ogmatics and } \\
\text { s, Faculty of } \\
\text { ersity of }\end{array}$ \\
\hline $\begin{array}{l}\text { Correspondin } \\
\text { Calvyn du Toit } \\
\text { calvyn@outlo }\end{array}$ & $\begin{array}{l}\text { g author: } \\
\text { ok.com }\end{array}$ \\
\hline $\begin{array}{l}\text { Dates: } \\
\text { Received: } 25 \mathrm{~J} \\
\text { Accepted: } 23 \\
\text { Published: } 28\end{array}$ & $\begin{array}{l}\text { an. } 2018 \\
\text { Mar. } 2018 \\
\text { May } 2018\end{array}$ \\
\hline $\begin{array}{l}\text { How to cite th } \\
\text { Loubser, G.M. } \\
\text { 2018, 'Resusc } \\
\text { Hollywood, Bi } \\
\text { transdisciplinz } \\
\text { HTS Teologies } \\
\text { Theological St } \\
\text { 4921. https:// } \\
\text { 10.4102/hts.v }\end{array}$ & $\begin{array}{l}\text { is article: } \\
\text { \& Du Toit, C.C., } \\
\text { tating myth: } \\
\text { g History and } \\
\text { iry theology', } \\
\text { e Studies/ } \\
\text { udies } 74(4) \text {, } \\
\text { doi.org/ } \\
74 \text { i4.4921 }\end{array}$ \\
\hline $\begin{array}{l}\text { Copyright: } \\
\text { (c) 2018. The } \\
\text { Licensee: AOS } \\
\text { is licensed un } \\
\text { Creative Comr } \\
\text { Attribution Lic }\end{array}$ & $\begin{array}{l}\text { Iuthors. } \\
\text { IS. This work } \\
\text { ler the } \\
\text { nons } \\
\text { ense. }\end{array}$ \\
\hline Read online: & \\
\hline 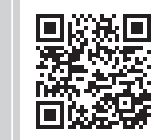 & $\begin{array}{l}\text { Scan this QR } \\
\text { code with your } \\
\text { smart phone or } \\
\text { mobile device } \\
\text { to read online. }\end{array}$ \\
\hline
\end{tabular}

Authors:

Affiliations:

and Christian Ethics,

Faculty of Theology and

Religion, University of

Research Project Registration:

Project Leader:

D.P. Veldsman

Project Description:

The authors are participatin

'Religious Experience from

an evolutionary perspective',

directed by Prof. Dr Veldsma

Department Dogmatics and

Corresponding author:

Calvyn du Toit,

Dates:

Accepted: 23 Mar. 2018

How to cite this article: Loubser, G.M. \& Du Toit, C.C. 2018, 'Resuscitating myth: Hollywood, Big History and HTS Teologiese Studies/ Theological Studies 74(4), 4921. https://doi.org/

Copyright:

(C) 2018. The Authors. Licensee: AOSIS. This work Creative Commons Attribution License.

mobile device
to read online.
Expanding our description of liturgy as an organisation of technics structuring desire, we describe the accompanying myth as a technic of knowing. Drawing on transdisciplinary theology, developed from the work of Wentzel van Huyssteen, Paul Cilliers and Alfonso Montuori, we engage the cross-disciplinary construction of scientific myth by Big Historians. We argue that myth, as a transversal technic of knowing, is abundant in many spheres of our lives and bridges what Bernard Stiegler calls the persistent minimal gap between humanity and technics. Can Big Historians offer such a bridge and what does it mean when scientists use technicities developed by religious practitioners?

\section{Introduction}

In an earlier article, we postulated liturgy as not in the first place a structuring of desire but rather a structuring of technics. Such alignment, in turn, elicits desire into a consistency for care in the pharmakon created by technics. Technics, of course, refers to tertiary, externalised memory on which humans draw to construct selves. The essay ended by citing Victor Hugo's (2011:137) aphorism from Notre dame de paris: 'Ceci tuera cela. Le livre tuera l'édifice [This will kill that. The book will kill the building]'. Indeed, today Christian liturgy faces a challenge of there and back again - the textual usurped the visual just, so the latter could return with a vengeance.

By drawing on new technics, Christian liturgy may contribute to pulling the pharmakon created by the new emerging technical epoch from scattered confusion into thoughtful care. It is worth recapping the importance and strangeness of technics' pharmacological texture. Plato's use and suspicion of writing and rhetoric intrigued Derrida. In his work Positions, the French-Algerian names pharmakon as one of the terms that find no correspondence with metaphysical being in the history of philosophy (Derrida 1972a:43). Later, in La pharmacie de Platon [Plato's pharmacy], he investigates and deconstructs Plato's (2011) use of pharmakon with a particular focus on the Greek philosopher's dialogue Phaedrus (Derrida 1972b:69-198).

Plato remains ever critical of writing and thus forgetful of how his whole enterprise relies on this very externalised memory aid he ostensibly detests. Unlike Plato, Derrida insists that one should acknowledge writing as one of many externalised technics which creates a pharmacological potential. Thus, if handled with the needed care, writing becomes key to the formation of an ethical individual. Later, Stiegler (1998), by fusing Derrida's insight with Simondon's, extends technics' pharmacological texture to encompass economy, technology and politics.

Now, this article tackles the inverse of the earlier one. Here, the possibility of technics structuring desire through liturgy is not the focus but investigating a grounding myth behind such structuring of desire. In a sense, the earlier article hinted at this when challenging Smith's (2009:82-83) willynilly attribution of thick and thin ritual. Not acknowledging how industrial complexes arrange technics to produce rituals means getting stuck with a master, like Smith, who arbitrates normative interpretations.

This article then describes myths as contextual arrangements of technics. Such an investigation is key; every thinker who considers technics as pharmakon leverages myth as origin but forgets nominating myth as a technic. So, Plato in the Phaedrus starts with the Egyptian myth of Theuth and Thamus, while Stiegler prefers the myth of Prometheus and Epimetheus. Thus, as we explore modern myths here, our aim is cultivating an awareness and evaluation of the developing myth of Big History as a technic of knowing with the hope that more care might be elicited from myth as a technic.

In Ambiguity in Star Wars and Harry Potter, Christina Flotmann (2013:7-27) argues that origin stories, myths, 'has nowadays found their way into popular culture and survive in secularized 
form'. She follows Lévi-Strauss in describing myths as attempts to reconcile conflicting aspects of life. Myths lay bare the desire for security and moral clarity. These, however, come at a price because myths can 'facilitate the generation of ideology'. Myths, like pharmakia, are ambiguous in providing comfort while distorting and manipulating desire. Myths are not only stories. They are in dynamic relation with liturgies, inviting practitioners to behave in particular ways:

$[I] \mathrm{t}$ has been established that myth helps mankind deal with existential fears and grow spirituality, caters to the human need for transcendence and functions as behavioral guide. Stories such as Star Wars and Harry Potter ... fulfill at least some of these functions, because they, too feature heroes who go through spiritual crises and through whom people can experience these crises themselves, one step removed from reality. (Flotmann 2013:31)

For Flotmann (2013:31), myths perform four functions. Firstly, 'by working with polarities, myth lays bare the structures of human thought'. Secondly, myths have a practical and didactic function, namely structuring desire. Thirdly, myth 'exposes the limitations of a closed language system, which cannot transcend binaries'. Lastly, myth offers a discernible message and several hidden ones, which gives myth its enigmatic quality. Films such as Star Wars and Harry Potter show the ambiguousness and dark side of myth ripe for ideological manipulation. 'Our mythology ... is the electronic archiving of quantified individuality according to scientific methods, and an implementation of this process in order to serve capitalism upon which our economy is based' (Mackey in Flotmann 2013:15).

Joseph Campbell $(1949: 24,369)$ suggests that myth supplies the 'symbols that carry the human spirit forward' and mythology 'is psychology misread as biography, history and cosmology'. Campbell (1949) writes:

The modern psychologist can translate it back to its proper denotations and thus rescue for the contemporary world a rich and eloquent document of the profoundest depths of human character. (p. 367)

Campbell (1949:369-370), like Flotmann, thinks mythologies contain symbols of the unconscious and are 'controlled and intended statements of certain spiritual principles which have remained as constant throughout the course of human history as the form and nervous structure of the human physique itself'. Campbell draws on C.G. Jung, for whom myth is a 'psychic phenomena that reveal the nature of the soul' (Botha 2006):

$[M]$ an creates myths in an attempt to understand himself, for the archetypes of his unconscious are only visible in the rational consciousness when manifested. If the archetypes are lifestructuring possibilities latent in the psyche, then it is the function of myth to indicate the 'typical probabilities' of life by giving concrete forms of the archetypes. (p. 7)

An upcoming section will show Campbell and Flotmann's view of the genetic-phylogenetics-epiphylogenetic exchange and counter-exchange as limited.
Even without the benefit of a rigorous memory theory, Campbell (1949:387) argues that mythology's basic principle is narrativising the beginning and the end of history. However, the modern age interprets myth:

- as 'fumbling effort to explain the world of nature'

- 'production of poetical fantasy from prehistoric times, misunderstood by succeeding ages'

- 'repository of allegorical instruction, to shape the individual to his group'

- 'group dream, symptomatic of archetyped urges within the depths of the human psyche'

- 'traditional vehicle of man's profoundest metaphysical insights'

- 'as God's Revelation to His children'. (Campbell 1949:552)

Campbell explains a myth's interpretation with each interpreter, and thus one or more of the above aspects feature in many modern interpretations. Campbell (1949:553) writes: '[M]ythology shows itself to be as amenable as life itself to the obsessions and requirements of the individual, the race, the age'.

Campbell (1949:562-563) suggests our focus shifted from the group to the individual. This change, along with bounded nations transitioning to a global society, transformed mythology from a connecting enterprise to a dividing tool. As such, we live in a demythologised world and what 'we learn in schools is not the wisdom of life', but the information and technologies of the day (Campbell 1991:47-48). We have become specialists who reduce our field of problems to that which our specialisation allows. Mythology is the game of the generalist who 'gets into a range of other problems that are more genuinely human'.

\section{Campbell offers four functions of myth:}

1. Mystical: '... realizing what a wonder the universe is, and what a wonder you are, and experiencing awe before this mystery'.

2. Cosmological: ' $\ldots$ the dimension with which science is concerned'. Scientists tell us how things work.

3. Sociological: an out-of-date function in its current form in contemporary society.

4. Pedagogical: '.. how to live a human lifetime under any circumstances'.

Campbell (1991:84) distinguishes between how mythology 'relates you to your nature and to the natural world, of which you're a part' and how mythology 'is strictly sociological, linking you to a particular society'. He suggests we need a myth that will identify the individual with the planet (Campbell 1991:88). Enter Big History as a contemporary myth.

\section{Big History}

Big History is a myth generated and facilitated by historians offering a way of understanding humanity as part of an evolving universe. Big Historians, drawing on specific 
technics to achieve a particular coherence, offer a scientifically sound creation myth conducive to an ecologically relevant spirituality.

David Christian (2011:1), a historian, argues that 'modern science can help us answer some of the deepest questions we can ask concerning our own existence, and that of the universe through which we travel'. He argues that modern science offers everything we need to generate a memorable and authoritative creation myth, which provides 'universal coordinates within which people imagine their own existence and find a role in the larger scheme of things'. He recognises creation myths 'speak to our deep spiritual, psychic and social need for a sense of place and a sense of belonging'. Christian (2011) argues that modern science is the narrator of our contemporary creation myth:

$[T]$ here is an astonishing power to any story that attempts to grasp reality whole. This power is quite independent of the success or failure of any particular attempt; the project itself is powerful, and fulfils deep needs. (p. 3)

Christian observes that critique of disciplinary specialisation and fragmentation alludes to the need to understand reality as a whole. So, he proposes an underlying unity and coherence beneath the diversity and complexity of modern thought, which can serve as the foundation for our creation myth. However, he also recognises the relation between knowledge and knower, which means that no contemporary creation myth is neutral (Christian 2011:6-8). Creation stories are particular to communities, but 'in a world with nuclear weapons and ecological problems that cross all national borders, we desperately need to see humanity as a whole':

[K]nowledge systems, like maps, are a complex blend of realism, flexibility, usefulness, and inspiration. They must offer a description of reality that conforms in some degree to common sense experience. But that description must also be useful. It must help solve the problems that need to be solved by each community, whether these be spiritual, psychological, political, or mechanical. (p. 11)

Fred Spier (2010:ix) confesses that deep ecological concerns motivate his understanding of Big History. Spier proposes that Big History 'helps us to create a novel theoretical framework within which all scientific knowledge can be integrated in principle ${ }^{\prime}-$ a theory of everything.

Furthermore, Spier (2010:7) observes history, as an academic discipline, emerged at the same time as European and American nation states in the 19th century. Writing history is, amongst other things, crafting purposeful identities. Big History can, Spier argues, produce purposeful identities on a global scale. Here, a simple objection is identity begets antiidentity - the contemporary tendency to revisit national identities against the complex global identity thrusted upon people is one example. In partnership with Bill Gates, The Big History project developed a free online course focused on educators and students. By utilising the digital network technology's extensive reach, The Big History project connects communities across the globe.
Big History, however, also has a history. Spier (2010:10-14) identifies past Big History writers. Alexander von Humboldt set out to develop a whole story of nature using science alone. Paul-Henri d'Holbach rejected any religious explanations of nature and moral rules. Moreover, David Hume, Edward Gibbon, Williams Robertson and François-Marie Arouet de Voltaire all 'distanced themselves from religious approaches' and René Descartes analysed the heavens without referring to divine intervention'.

Spier also describes Immanuel Kant and Georg Hegel as forerunners of Big History. According to Spier, Robert Chambers' work paved the way for Charles Darwin's theory of evolution and H.G. Wells' Big history which intended to foster a global identity preventing major wars. However, Spier describes Erich Jantsch (1980) as the first to develop a systematic model for Big History in The selforganizing universe. Spier (2010:24) shares Jantsch's sentiment that Big History 'deals with the emergence and decline of complexity' and offers complexity as a universal scientific language:

This approach may actually constitute an entire interdisciplinary research agenda that, if pursued, would allow scientists ranging from astronomers to historians and anthropologists to collaborate in unprecedented ways while speaking the same scientific language. (p. 39)

Michael Dowd (2007), an evolutionary evangelist, celebrates the unifying ability of science because we have to learn how to organise and govern ourselves on a global scale. Dowd (2007) writes:

Traditional religions have played crucial roles in fostering cooperation within each tribe, kingdom, and early nation though not infrequently by provoking suspicion and enmity of those outside the group. Now emerging is an orientation that encourages wider affinities and global-scale cooperation. For religious traditions to fulfill their potentials in our postmodern world, each will be called to harmonize its core doctrines with the evolutionary worldview. (pp. 3-4)

Dowd's acclaimed book Thank God for evolution! deals with complex topics such as 'the marriage of science and religion', 'science and religion spurring each other to greatness' and 'meaning-making' without referring to the massive body of work by scholars such as Ian Barbour on critical realism, Arthur Peacocke on panentheism, John Polkinghorne on the theodicy, Wentzel van Huyssteen on post-foundationalism, Niels Gregersen on deep incarnation and others. Furthermore, he claims revelation for science in 'facts are God's native tongue', 'what do we mean by the Word God' and 'REALizing the Gospel'. He also discusses identity formation in 'cultivating discernment within the whole' and 'aligning self-interest with the wellbeing of the whole'. Moreover, Dowd looks to the future in 'likely Good News in the next 250 years' and 'REALizing Godly morality and Ethics'. Most intriguingly, Dowd (2007) addresses a wide variety of people from all religions, ideologies and their critics and promises that his book will strengthen relationships: 
To those with loved ones who have been unable to embrace science because of their religious faith, and those with loved ones who have been unable to embrace religion because of their scientific worldview, I promise that sharing this book will make a difference in your relationship. Discussing Thank God for Evolution! with those you care about will open new doors of possibility between you and provide common ground where none existed before. This book is a perfect gift, not to convert others to your way of thinking but to converse with them deeply and heartfully about those things that matter most. (p. xxii)

Evolution frees religious insights and perspectives from the narrow confinements of their origins and offers global significance as religious traditions foundationally embrace a scientifically developed cosmology (Dowd 2007:6, 7, 28). However, we cannot thrive without myth, because we draw on this technique (or mythopoeic drive) to generate meaning as individuals and collectives:

Science unquestionably provides the foundation. For this tale to be experiences as holy, however, it must don the accoutrements of myth. Bare-bones science must be embellished with metaphor and enriched by poetry, painting, song and ceremony. (Dowd 2007:19)

This Great Story, the scientific creation myth, is ongoing and offers a planetary perspective. It 'seamlessly weaves together science, religion, and the needs of today's world'. It is a metareligious perspective that 'fulfils its potential for humanity only when it is taken into and absorbed independently by each faith and worldview'. Dowd (2007) writes:

The discovery of facts through science is one very powerful way to encounter God directly. It is through the now-global community of scientists, working together, challenging one another's findings, and assisted by the miracles of technology, that God's Word is still being revealed. (p. 71)

The Great Story, as our evolutionary creation myth, can also inform our ethics, spirituality and communal living through its main teaching - evolutionary integrity. Dowd (2007:129, 133) explains that The Great Story 'can catalyse spiritual and psychological transformation more consistently for modern people than can any of the creation stories born of prior ages'. Why? Because evolutionary sciences, such as evolutionary brain science and evolutionary psychology, 'provide a more realistic and universally relevant picture of the human condition than was possible when the Hebrew people acquired the creation story'. Evolutionary integrity would also mean we create social institutions that honour diversity and dissonance.

Big History, however, builds upon the precise liturgical structures which our earlier article argued, scatters desire (Du Toit \& Loubser 2016). As such, Big History faces the dilemma of inculcating adherence without attention. The danger being, of course, that Big History gets dumped into the backwaters of the very system which produced it. Before continuing, a short note on science and myth as forms of knowledge.

Big History practitioners want to unify the sciences, disciplines and people; however, they also exclude many aspects of humanity and human knowledge. Big History needs not be such a reductive enterprise. William Katerberg (2015:4-8) observes that Big History does not draw on science alone. Big History practitioners also draw on intellectual history, philosophy, political theory, theology and literary criticism. Furthermore, he observes that mythologies are teleological, and Big History has a deep ecological teleology. Moreover, Katerberg observes that Big History draws on complexity, a tradition against reductionism, but then builds on the reductionist knowledge of the sciences too. They should be sceptical of a unified science. He writes:

If we humans are to have a meaningful sense of our place in the universe and if we are to care about and for our planet, the philosophical and religious questions raised by emergence and teleology need to be addressed, and they must be recognized as challenges to naturalism and as going beyond 'normal science.' Big History provides an ideal place to discuss questions like these. It would be an intellectual and civic failure to avoid the opportunity rather than embrace it. (p. 6)

Katerberg's suggestion is important because scientific methods may offer common ground, but never neutral ground. As such, Big History's 'modern creation myth' is still teleological. Humanity 'falls' from a sustainable way of life but can find 'redemption' through ethical life choices. The Big History's 'evolutionary epic' remains anthropocentric and anthropomorphic (Arnhart 2016).

\section{Myth}

In our scientific epoch, myth often means pre-scientific or even non-scientific forms of knowledge. However, we propose myth is not a quality of knowledge, but rather a technique of knowing. Busting myths may render our understanding more scientifically sanitised, but it also narrows our understanding. Knowledge sanitation, for example, forces the abeyance of meaning, death, narrative and mystery. Big History, Star Wars and Harry Potter show us myth as technicity is very much alive, even though we have curtailed its worth and applications.

We argue for myth as a transversal technique of knowing. Myth engages not only multiple disciplines, but different disciplines also cultivate unique uses of myth. As such, we need to engage diverse and distinct disciplines in our discussion and description of myth. Transdisciplinary theology offers a progenitive and appropriate approach to describe and understand myth as using technicity to cover the spirituality gap.

Transdisciplinary theologians recognize the knower in generating knowledge (Loubser 2017:2). They focus on specific scholars and their specific approach to specific problems because they recognise the role of the modeller in generating scientific or theological knowledge and solutions. Furthermore, transdisciplinary theologians engage issues disclosed through lived experience, which means that their reflection already includes the audience's context. Transdisciplinary theologians also appreciate that disciplines are open, have 
histories and are in disequilibrium and so offer knowledge or models that embrace the social histories of disciplines and the environment in which they operate.

Moreover, transdisciplinary theologians argue that one way to enrich disciplinary research is to question disciplinary assumptions and disciplinary fragmentation. Most importantly, transdisciplinary theologians argue that disciplines relate to each other transversally, and so appreciate the significance of transversal shifting. However, Big Historians describe their approach as cross-disciplinary and therefore do not necessarily engage disciplines transversally. In other words, Big Historians try to merge knowledge from diverse disciplines in a single story, decontextualising knowledge from the people and environment producing it. In short, Big Historians may distort the intention and use of knowledge when using it for their purposes.

\section{A history of mythology}

Robert Segal (2015:1-4) notes that our understanding of myth has not been a unified experience. He explains how anthropological theories of myth link to culture while psychological and sociological theories link to the mind and society, respectively. Segal argues that each discipline offers its own answers, but what unites mythologies is the questions asked about origin, function and subject matter. Nineteenth-century theories tend to regard myth as explanations of the physical world and thus as a counterpart to science. Later theories do not pit myth against science, and describe myth as 'a story about something significant that accomplishes something significant for adherents'. Interestingly, Segal holds most theorists after the 19thcentury defined myth as 'a story which can, of course, express a conviction, must have a powerful hold on its adherents.

Lévy-Bruhl, for whom myth is the opposite of science, suggests that primitive cultures used religion and myth to commune with the world (Segal 2015:22, 23). Karl Popper, who likewise places myth over against science, argues that content does not demarcate myth and science, but the attitudes towards them (Segal 2015:27). Dogmatic acceptance marks religious myths, while constant questioning designates scientific knowledge.

Demythologised descriptions of myth shifted the subject of myth from the physical world to the experience of living in the world. Segal (2015:38) writes: 'Demythologized, myth ceases to be an explanation at all and becomes an expression, an expression of what it "feels" like to live in the world".

Exemplars of such demythologising are Hans Jonas and Rudolf Bultmann who still found myth significant (Segal 2015:42). Bultmann (1984a:3-9) insists on the impossibility of a mythological world view 'now that all of our thinking is irrevocably formed by science'. Bultmann argues that myth should not be understood in cosmological terms, but in anthropological terms. Bultmann (1984a) writes:

What is expressed in myth is faith that the familiar and disposable world in which we live does not have its ground and aim in itself but that its ground and limit lie beyond all that is familiar and disposable and that this is all constantly threatened and controlled by the uncanny powers that are its ground and limit. (p. 10)

Bultmann (1984b:95) argues that mythological and scientific thinking is opposite. However, aetiological myths are attempts to explain natural phenomena, but are quite different to the apocalyptical mythology of the New Testament. Bultmann proposes a process of demytholisation through which we can distil the intention of the myth. Bultmann (1948b) writes

Demythologization seeks to bring out the real intention of myth, namely, its intention to talk about human existence as grounded in and limited by a transcendent, unworldly power, which is not visible to objectifying thinking. (p. 99)

Rasmussen (1971:10-19) suggests that Bultmann takes all myth as aetiological. Bultmann's aetiological reading then frees myth from the pre-scientific, making it translatable for modern humans. Thus, myth becomes a hermeneutical problem. Rasmussen, however, argues that the understanding of myth relates to assumptions about being human.

[T] he acceptance or rejection of mythic discourse will depend upon whether or not one assumes that a mythic mentality is a product of a particular historical period with the associated assumption that contemporary man has 'come of age' and is, therefore, beyond that historical period. The alternative assumption is that myth is a constitutive expression of human consciousness regardless of the particular period in which it was produced. (Rasmussen 1971:17)

Rasmussen conveys, how for Levy-Bruhl myth refers to a primitive mentality, while for Levi-Strauss myth does not refer to the quality of thought, but rather to the nature of things to which it is applied. For Bultmann, myth refers to a different world view. Bultmann's mistake was to argue for the elimination of myth on the basis of an anthropology that pre-supposed a historical evolutionary hypothesis.

Rasmussen (1971) agrees with Ricœur who argues that myth is a necessary informant of knowledge and offers a threefold myth definition:

[F]irst, as that which unites man in an exemplar history, thereby giving a definition to man and humanity; second, myth tells a story which combines fable and history; and third, myth attempts to explain the enigma of human history, placing within its story the explanation for man's particular problem. (p. 81)

For Ricœur (in Malan 2016), a global anthropology has as a concrete correlate dimension a mythic-symbolic language:

To understand myth as myth is to understand what the myth, with its time, its space, its events, its characters, its drama, adds to the revelatory function of the primary symbols. (p. 2) 
Theorists in the 20th century spurned 19th century descriptions of myth for (Segal 2015:122):

- 'pitting myth against science and thereby precluding traditional myths ...'

- 'subsuming myth under religion and thereby precluding secular myths ...'

- 'deeming the subject matter of myth, the physical world ...'

- 'deeming the function of myth explanatory ...'

- 'deeming myth false'.

Contemporary discussions of myth have attempted to recharacterise myth and bring it back to the physical world, 'but without facilely dismissing the authority of science' (Segal 2015:122). Herein lies the ingenuity of Big History.

\section{Stiegler: Myth as technicity}

Now, with a better description of the field of mythmaking, one can assess myth as technicity. Firstly, myth as technique of knowing, rather than a quality of knowledge, needs further explication. Such clarification starts with attending to continental philosophy's so-called technological turn (Bradley \& Armand 2006:1-14). For technological-turn thinkers, technics names more than technology produced since the industrial revolution; technics designates tertiary memory (Stiegler 1998:245-250).

First-order memory describes an event's unfolding; that is, the sequential flow of moments. This sequential flow harbours the instant before and anticipates the time after cognition (Husserl 1991:21-46). Secondary memory, in turn, hints at the memory recall of a single contingent entity, such as a human. Such secondary memory may transfer to future offspring through genetic changes started in said individual (Ross 2013:248). The tertiary memory of technics is any externalised body which survives longer than a temporal event or a single entity's contingent genetic memory. Technical organs encompass cultural and social structures, writing, produced objects, and so on.

Technics carry producers' collective memory. Producing tertiary memory, however, also means forgetting. In other words, the manufacturers and assemblages leveraged to create technics are disremembered. When using a toaster, for example, one needs not cognise Lloyd Groff Copeman's history. Nor does one need to understand the workings and history of every module making the toaster possible. Such amnesia produces, what Latour (1987:1-20), borrowing from cybernetics, calls black boxes - objects accepted and built upon without awareness of its synchronic or diachronic depth. Black boxes, when opened, release their forgotten memory. Yet, how do these concepts apply to myth and spirituality?

Firstly, spiritualities have first-order memory. Spirituality is impossible without an uncanny encounter as well as the biological circumstances ripe for such a happening. Secondly, such eerie events may retain weight through secondary memory by, for example, personal genetic and cognitive retention, which creates new hereditary likelihoods. Finally, individuals share a spiritual event by leveraging tertiary memory. In other words, a particular arrangement of technicities, such as language, writing, stabilised systems or communities, grows and develops spiritualities. Tertiary memory's production includes, however, forgetting. The first forgetfulness, so to speak, is how the externalisation of mysterious happenings is conditioned and produced by technics in the first place (Stiegler 1998:169-170).

Now, one comes to the crux of spirituality and myth as a technique of knowing. Humans cannot ponder spirituality (or for that matter anthropology or anthropogenesis) outside the black box states created by technics. So, tracing the origins of the dialectic between technics and humanity always hits an event horizon. Not only are the very tools of enquiry already inscribed with millennia of remembering and forgetting, but also access to early humankind is through the technics they left behind.

So, there remains an always persistent minimal knowledge gap between humanity and technics which needs bridging. Here, spiritualities have often leveraged myth as a technique of knowing - a speculative attempt to push beyond the known. Myths, therefore, are a particular way of arranging symbols, that is, tertiary memory, which covers but never heals the dialectic wound producing the human. Now, one can assess the shortfalls of two approaches to spirituality.

Waaijman (2002:1), for example, enamoured by existential phenomenology insists on an Absolute vacillating between the foreground and background of human consciousness. The problem with Waaijman's approach becomes clear once one considers the human-technics gap. Waaijman should answer the question: how is the Absolute not an arbitrary calcified covering of the technics-human gap - a black box of being? Waaijman does not, however, discuss this issue. Unaddressed, the spirituality gap calcified as Absolute, becoming a bi-conditional for anything imaginable.

Next, we turn to Hefner's (2003:39) claim that spirituality is human self-transcendence. He often invokes Tielhardian sounding transhuman dictum, 'humans are nature becoming aware of itself'. Hefner's mistake is forgetting the redoubling of technicity. For Hefner, technicity and spirituality is a oneway street, which seems wrong. As Stiegler notes, technicity redoubles. Human capacities, ambitions and choices are shaped by the conditions created by technicities just as much as we shape them. Humans have always been existential cyborgs coming into being in sync with technics.

Where does this leave myth as a technique of knowing? Well, building bridges across the technical self's spirituality 
gap means constructing myths through technics. In other words, myths are retroactive and redoubled technical aetiologies inventing the self. So, spirituality lives in and shows the originary gap that necessitates myth. Myths aim at sustaining systems, which may in the long term turn out to be, under particular circumstances, one of care or harm. Myth always leverages various disciplines to produce an atmosphere with the potential for care or harm - its pharmakon.

\section{Possible conclusion}

Every technical arrangement establishes not only an externalised memory, but also a forgetting. Ceci tuera cela. Le livre tuera l'édifice [This will kill that. The book will kill the building]. One should thus ask, as far is possible from our limited perspective, what Big History forgets when making myth.

For now, it is enough to notice that like any pharmakon created through technical arrangement, Big History has the potential to both heal and harm. Yes, Big History provides an accessible overview of the story science tells about our world. However, history remains a story we, humans, tell each other. The adage that history is not an anonymous, objective exercise holds. Someone writes histories by selecting from available data; a bigger history means more hidden predeterminations.

We would do well to remember 6.371 and 6.372 of Wittgenstein's (1974) Tractatus logico-philosophicus:

whole modern conception of the world is founded on the illusion that the so-called laws of nature are the explanations of natural phenomena. (6.371)

Thus people today stop at the laws of nature, treating them as something inviolable, just as God and Fate were treated in past ages. And in fact both are right and both wrong: though the view of the ancients is clearer in so far as they have a clear and acknowledged terminus, while the modern system tries to make it look as if everything were explained. (6.372)

If one was in a Wittgenstein state of mind, and one should be wary of coagulating into such a state, one may ask if Big History is not the start of theologising natural laws. Natural laws are handy human abstractions but do not correspond exactly with reality. Non-correspondence does not mean that natural laws are not true, but it means that natural laws are always abstracted and are true enough. Most eminent 'hard' scientist acknowledges their enterprises' indirectness. When one, however, mythologises the natural laws, does one not disavow the temporality of our knowledge? This question is addressed in a forthcoming article in collaboration with a socalled hard scientist. There we will consider various myths and stories and how they potentially curtail inquisitiveness. For now, one should remain sceptical.

\section{Acknowledgements Competing interests}

The authors declare that they have no financial or personal relationships which may have inappropriately influenced them in writing this article.

\section{Authors' contribution}

Both authors equally contributed to the research and writing of this article.

\section{References}

Arnhart, L., 2016, Is Big History science or myth? Or both?, Blog, Darwinian Conservatism, viewed 26 May 2016, from http://darwinianconservatism. blogspot.co.za/2016/02/is-big-history-science-or-myth-or-both.html

Botha, J., 2006, 'The myth is with us: Star wars, Jung's archetypes, and the journey of the mythic hero', M.Phil thesis, Stellenbosch University, South Africa.

Bradley, A. \& Armand, L., 2006, 'Thinking technicity', in A. Bradley \& L. Armand (eds.), Technicity, pp. 1-14, Litteraria Pragensia, Prague.

Bultmann, R., 1984a, 'New Testament and mythology: The problem of demythologizing the New Testament proclamation', in S. Ogdened (ed.), New Testament and mythology and other basic writings, pp. 1-34, Fortress, Philadelphia, PA.

Bultmann, R., 1984b, 'On the problem of demythologizing', in S. Ogdened (ed.), New Testament and mythology and other basic writings, pp. 95-130, Fortress, Philadelphia, PA

Campbell, J., 1949, The hero with a thousand faces, HarperCollins, New York.

Campbell, J., 1991, The power of myth, Anchor Books, New York.

Christian, D., 2011, Maps of time: An introduction to Big History, University of California, Berkley, CA.

Derrida, J., 1972a, Positions, Minuit, Paris.

Derrida, J., 1972b, 'La pharmacie de Platon', in La dissemination, Seuil, Paris.

Dowd, M., 2007, Thank God for evolution! How the marriage of science and religion will transform your life and our world, Council Oak Books, San Francisco, CA.

Du Toit, C.C. \& Loubser, G.M., 2016, 'Liturgical pharmacology: Time of the question, complexity and ethics', HTS Teologiese Studies/HTS Theological Studies 72(1).

Flotmann, C., 2013, Ambiguity in Star Wars and Harry Potter: A (Post)structuralist reading of two popular myths, Columbia University, New York.

Hefner, P.J., 2003, Technology and human becoming, Fortress, Minneapolis, MN.

Hugo, V., 2011, Notre dame de Paris, Norph-Nop Edition.

Husserl, E., 1991, On the phenomenology of the consciousness of internal time (1893-1917), Kluwer Academic, Boston, MA.

Jantsch, E., 1980, The self-organizing universe, Pergamon, Oxford, UK.

Katerberg, W., 2015, 'Myth, meaning, and scientific method in Big History', Origins 5(12), 3-12.

Latour, B., 1987, Science in action, Harvard University, Cambridge, MA.

Loubser, G.M., 2017, 'The dynamics of theologies: A transdisciplinary description', HTS Teologiese Studies/HTS Theological Studies 73(3). https://doi.org/10.4102/ hts.v73i3.3866

Malan, G., 2016, 'Ricoeur on myth and demythologising', HTS Theological Studies 72 4. https://doi.org/10.4102/hts.v72i4.2998

Plato, 2011, Phaedrus, Cambridge University Press, New York.

Rasmussen, D.M., 1971, Mythic-symbolic language and philosophical anthropology Martinus Nijhoff, The Hague.

Ross, D., 2013, 'Pharmacology and critique after deconstruction', in C. Howells \& G. Moore (eds.), Stiegler and technics, pp. 243-258, Edinburgh University, Edinburgh.

Segal, R., 2015. Myth: A very short introduction, Oxford University, New York.

Smith, J.K.A., 2009, Desiring the kingdom: Worship, worldview, and cultural formation, Baker Academic, Grand Rapids, MI.

Spier, F., 2010, Big history and the future of humanity, Wiley Blackwell, Malden, MA.

Stiegler, B., 1998, Technics and time, 1: The fault of Epimetheus, Stanford University, Stanford, CA.

Waaijman, K., 2002, Spirituality: Forms, foundations, methods, Peeters, Leuven.

Wittgenstein, L., 1974, Tractatus logico-philosophicus, Routledge, New York. 